\title{
Analisis Wacana Cerpen "Tinggal Matanya Berkedip-kedip" Karya Ahmad Tinjauan Aspek Sosial Budaya serta Penanda Kohesi Gramatikal dan Leksikal
}

\author{
Sri Widayati ${ }^{1}$ \\ Program Studi Pendidikan Bahasa dan Sastra Indonesia \\ STKIP Muhammadiyah Kotabumi
}

\begin{abstract}
Ahmad Tohari's short story entitled "Tinggal Matanya Berkedip-kedip" seen from social aspect depicts that authority and power of a leader supported by the power of "people live in poverty". Without civilian's support, a leader's power is priceless. Cohesion in grammatical aspect such as referent, substitution, ellipsis, and conjunction also appeared in the short story. The function of grammatical aspect is mainly to make the story more interesting. Cohesion in lexical aspect in the form of repetition and synonym used in the short story functions to strengthen the author's mind which delivered.
\end{abstract}

Keyword: social culture, cohesion, short story.

\section{Pendahuluan}

Dalam perkembangannya, dari segi bentuk dan panjangnya, cerpen merupakan karya sastra yang paling cepat dan mudah beradaptasi dengan lingkungan media bukan sastra, misalnya koran. Entah berapa ratus cerpen terpublikasikan di media pada setiap bulannya, sebab hampir semua majalah hiburan dan surat kabar umum yang memiliki edisi minggu menyediakan rubrik khusus cerpen.

Cerpen sebagai suatu karya sastra yang relatif pendek, dengan hanya beberapa halaman, dengan kalimat-kalimat realis yang sederhana, terbukti sanggup membuktikan kosmos suatu kondisi dengan tampilan yang utuh. Dengan kecenderungan untuk tidak berkhotbah, cerpen dengan cukup sarat pasti mampu menggambarkan bahwa konflik dengan kekuatan eksternal. Begitu pula konflik internal yang dibangun pada unsur-unsur kohesif yang membentuk wacana cerpen, lewat penggambaran tokoh, adegan, dialog-dialog yang diucapkan para tokoh pun ternyata mampu membangun suatu kesatuan yang padu.

Dalam tulisan ini akan dianalisis aspek sosial budaya serta penanda kohesi baik gramatikal maupun leksikal, pada sebuah cerpen karya Ahmad Tohari yang berjudul "Tinggal Matanya Berkedipkedip". Cerpen ini termasuk di dalam Kumpulan Cerpen Senyum Karyamin

Cerpen ini menggambarkan tentang tumbuhnya kesadaran bahwa kekuasaan, 
keahlian, atau pun kemenangan hanya akan bermakna dalam hubungannnya dengan sesuatu yang dikuasai, digarap, atau diperangi. Ahmad Tohari dengan cerdas mampu menggambarkan persoalan itu dengan sangat baiknya dalam cerpennya yang berjudul 'Tinggal Matanya Berkedip-kedip". Cerpen tersebut dibangun dengan alur nonkronologis yang membuatnya semakin memikat. Selain itu bahasa yang digunakan sangat sederhana sehingga mudah dicerna oleh siapa saja. Dengan gaya cerita yang mengalir dan gaya ungkap yang tidak menggurui, mengakibatkan pembaca tertarik untuk membaca lebih jauh, mengerti akhir ceritanya, dan memahami maknanya.

\section{Deskripsi Singkat Cerpen "Tinggal Matanya Berkedip-kedip"}

Cerpen "Tinggal Matanya

Berkedip-kedip ditulis oleh Ahmad Tohari. Ia kelahiran Tinggarjaya, Jatilawang, Banyumas 13 Juni 1948. Ahmad Tohari termasuk pengarang yang produktif. Di dalam karya-karyanya, ia banyak memotret realitas sosial yang terjadi di pedesaan, terutama realitas masyarakat pedesaan yang sarat dengan kemiskinan. Karya-karyanya yang lain dan telah terbit di antaranya adalah Kubah (1980), Trilogi Ronggeng Dukuh Paruk, Di Kaki Bukit Cibalak (1986), Kumpulan Cerpen Senyum Karyamin (1989), Bekisar Merah (1993), dan Lingkar Tanah Lingkar Air. Nama Ahmad Tohari menjadi sangat terkenal dengan novel Trilogi Ronggeng Dukuh Paruknya. Bahkan, novel trilogi tersebut sudah diterjemahkan ke berbagai bahasa.

Cerpen merupakan media yang efektif untuk mengungkapkan realitas sosial yang terjadi di masyarakat. Dengan cerita yang menarik, tahap-tahap ketegangan cerita, didukung dengan penciptaan karakter tokoh yang bervariasi menjadikan cerpen sebagai pilihan untuk itu. Berbeda dengan pidato atau khotbah yang lebih terkesan menggurui, di dalam cerpen pembaca lebih dihadapkan pada suatu fenomena dan akhirnya pembaca sendirilah yang akan mengambil makna dan nilai-nilai di dalamnya, untuk kemudian dijadikan sebagai perenungan, refleksi, dan juga kontrol sosial.

Melalui cerpen "Tinggal Matanya Berkedip-kedip" pengarang menceritakan tentang nasib malang seekor kerbau bernama si Cepon yang roboh di tengah sawah karena kesalahan seorang pawang yang tidak mau mencoba memahami "bahasa" binatang. Si Cepon adalah seekor kerbau yang gagah perkasa dan telah banyak berjasa sebagai pembajak sawah. Namun, belakangan binatang itu menjadi binal dan jalang sehingga ayah si "aku" (pencerita) merasa pusing dan sedih karena si Cepon tidak dapat membajak sawahnya. Oleh karena itu, sang ayah 
meminta bantuan pawang, yaitu Musgepuk yang sudah dikenal pandai untuk menjinakkan si Cepon.

Pada mulanya Musgepuk berhasil menjerat kerbau itu di kandang kemudian berhasil pula menjerat kaki-kakinya sehinga si Cepon terguling. Langkah selanjutnya adalah memasang seutas tali kaluh yang menembus hidung si Cepon. Tentu saja si Cepon kesakitan dan darah mengucur dari hidungnya. Akan tetapi, cara itulah yang sudah lazim diterapkan orang untuk menjinakkan kerbau atau sapi yang jalang. Dua hari kemudian, Musgepuk menggiring kerbau itu ke sawah, memasang bajak dan mulai memberi aba-aba kepada si Cepon dengan keyakinan penuh, usahanya akan behasil. Namun, si Cepon, tidak mau bergerak sedikit pun dan akhirnya roboh ke tengah sawah yang akan dibajak. Hanya matanya yang berkedip-kedip menandakan si Cepon masih bernyawa. Robohnya si Cepon itu ternyata mengisyaratkan kegagalam Musgepuk sebagai pawang yang sering bangga dengan keahliannya.

\section{Kajian Teoretis}

\section{Wacana Prosa}

Berdasarkan bentuk penyampaiannya, wacana dibedakan menjadi tiga, yakni wacana puisi, wacana prosa, dan wacana drama.Wacana prosa adalah wacana yang disampaikan dalam bentuk terurai. Wacana prosa dibedakan menjadi dua; yakni wacana prosa fiksi dan nonfiksi. Wacana prosa dalam pengertian kesusasteraan disebut prosa fiksi, teks naratif (narrative text) atau wacana naratif (narrative discourse). Istilah prosa fiksi dalam hal ini berarti cerita rekaan atau cerita khayalan (Nurgiyantoro, 2010:1). Dengan demikian, prosa fiksi adalah suatu karya prosa yang menceritakan sesuatu yang bersifat rekaan, khayalan, sesuatu yang tidak ada dan tidak terjadi sungguhsungguh sehingga ia tidak perlu dicari kebenarannya pada dunia nyata.

Isi wacana prosa, dapat juga berisi rekaman kehidupan manusia sehari-hari. Adapun bahasanya untuk teks sastra yang imajinatif, yaitu bersifat konotatif. Namun, sifat konotatif dalam prosa berkaitan dengan makna kias dan makna lambang (majas) diungkapkan dengan cara pembeberan.

\section{Cerpen}

Menurut Siswanto (2008:141142) cerita pendek merupakan bentuk prosa rekaan yang pendek. Pendek berarti mempersyaratkan adanya keutuhan cerita, bukan asal sedikit halaman. Pendek berarti juga permasalahan yang digarap tidak begitu kompleks. Menurut Djojosuroto (2009:173) cerpen adalah salah satu cipta sastra yang diciptakan dari aneka pengalaman batin pengarang. Pengalaman 
batin, pikiran, dan perasan pengarang dalam kehidupan sehari-hari.

Nurgiyantoro

mengatakan bahwa cerpen adalah cerita yang relatif pendek. Akan tetapi, berapa ukuran panjang pendek itu memang tidak ada aturannya, tidak ada satu kesepakatan di antara para pengarang dan para ahli. Kata pendek dalam batasan ini tidak jelas ukurannya. Panjang cepen itu sendiri bervariasi. Ada cerpen yang pendek, bahkan mungkin pendek sekali; berkisar 500-an kata; ada cerpen yang panjangnya cukupan, serta ada cerpen yang terdiri dari puluhan ribu kata

Berbeda dengan Allan Poe (dalam Nurgiyantoro 2010:10) yang mengatakan bahwa cerpen adalah sebuah cerita yang selesai dibaca dalam sekali duduk, kirakira berkisar antara setengah sampai dua jam satu hal yang tidak mungkin dilakukan bagi sebuah novel. Disebabkan oleh panjangnya, kemungkinan besar pembaca dapat menyelesaikan pembacaannya dalam waktu yang relatif singkat.

Berdasarkan pernyataan tersebut, dapat disimpulkan bahwa pengertian cerpen adalah suatu cerita yang relatif pendek, singkat jika dikaitkan dengan genre cerita hanya memiliki efek tunggal, dan bisa dibaca dalam sekali duduk.

\section{Kohesi (Keterkaitan)}

Pada tataran wacana kohesi (keterkaitan) adalah kaitan semantis antara satu proposisi atau kalimat dengan proposisi lainnya dalam wacana itu. Kaitan itu pada tataran wacana diperlihatkan oleh alat kohesi, yang dapat berupa unsur gramatikal maupun leksikal.

Kohesi menurut Junaiyah H.M. dan Arifin (2010:24-25) adalah kepaduan bentuk (bahasa) yang secara struktural membentuk ikatan semantis. Kohesi merupakan pertalian unit semantis yang diwujutkan ke dalam suatu bentuk, yang diwujudkan menjadi suatu ekspresi yang berupa bunyi (tulisan). Hubungan kohesif di dalam wacana dapat ditandai secara formal oleh pemarkah-pemarkah (alat kohesi). Pemarkah-pemarkah itu menghubungkan apa yang dikatakan dengan apa yang telah dinyatakan sebelumnya di dalam wacana itu. Pemarkah-pemarkah itu berfungsi mengikat dan membentuk keutuhan wacana. Kaitan itu diperlihatkan oleh alat kohesi yang dapat berupa unsur gramatikal maupun unsur leksikal.

a) Kohesi Gramatikal

Halliday dan Hasan (dalam Junaiyah dan Arifin, 2010:24) membagi kohesi gramatikal menjadi 4 macam, yaitu: (1) pengacuan (referensi), (2) penyulihan (subtitusi), (3) pelesapan (elipsis), dan (4) konjungsi. 
b) Kohesi Leksikal

Hubungan kohesi leksikal adalah hubungan kohesif wacana yang terjadi apabila dua unsur di dalam wacana dihubungkan melalui satu pengertian. Kohesi leksikal terutama ditampilkan oleh reiterasi. Menurut Halliday dan Hasan (dalam Zaimar dan Ayu Basoeki Harahap, 2009:140) ada bermacam-macam reiterasi, yaitu repetisi (pengulangan), sinonim, hampir sinonim, hiponim, dan kata generik.

\section{Metode}

\section{Data}

Di dalam tulisan ini akan disajikan data-data berupa penggalan kata-kata, kalimat, atau paragraf untuk mengidentifikasi unsur-unsur yang membangun karya sastra cerpen. Unsurunsur yang akan dibahas tersebut meliputi analisis situasi dan konteks sosial budaya dalam cerpen, serta identifikasi penanda kohesi baik gramatikal maupun leksikal dalam naskah cerpen.

\section{Sumber Data}

Seluruh data diperoleh dari naskah cerpen berjudul "Tinggal Matanya Berkedip-kedip" karya Ahmad Tohari. Cerpen tersebut diperoleh dari kumpulan cerpen Senyum Karyamin yang diterbitkan tahun 1994. Buku kumpulan tersebut terdiri dari 13 cerpen.

\section{Metode Analisis Data}

Metode analisis data yang digunakan dalam penelitian ini metode analisis deskriptif. Selain menggambarkan aspek sosial budaya dalam cerpen "Tinggal Matanya Berkedip-kedip", dilakukan juga pendekatan penulisan dengan interpretasi data. Pendekatan tersebut digunakan dalam menganalisis penanda kohesi dalam cerpen tersebut.

\section{Pembahasan}

\section{1) Analisis Situasi dan Konteks Sosial Budaya Cerpen "Tinggal Matanya Berkedip-kedip"}

\section{a. Analisis Situasi}

Si Cepon adalah seekor kerbau yang gagah perkasa dan telah banyak berjasa sebagai pembajak sawah. Namun, belakangan binatang itu menjadi binal dan jalang sehingga ayah si "aku" (pencerita) merasa pusing dan sedih karena tidak dapat membajak sawahnya. Oleh karena itu, sang ayah meminta bantuan pawang yaitu Musgepuk yang sudah dikenal pandai menjinakkan kerbau jalang. Namun, usaha musgepuk mengalami kegagalan karena dia justru hanya behasil merobohkan si Cepon. Dengan robohnya si Cepon itu ternyata mengisyaratkan 
kegagalam Musgepuk sebagai pawang yang sering bangga dengan keahliannya.

Dari aspek situasional tokoh utama, yaitu si Cepon akhirnya roboh. Robohnya si Cepon justru menyebabkan hancurnya kewibawaan Musgepuk sebagai pawang binatang piaraan. Dia yang terlalu membanggakan kepiawaiannya menjinakkan bintang piaraan menjadi tidak berdaya di hadapan si Cepon yang justru tidak melakukan perlawanan apa pun.

\section{b. Analisis Sosial Budaya}

$\begin{array}{ccr}\text { Cerpen } & \text { "Tinggal } & \text { Matanya } \\ \text { Bekedip-kedip" } & \text { berlatar } & \text { budaya }\end{array}$
masyarakat Jawa, terutama masyarakat Jawa dari kelas sosial masyarakat bawah. Penanda dari kelas sosial masyarakat bawah adalah nama tokoh-tokohnya yang dihadirkan pengarang seperti si Cepon dan Musgepuk. Dalam konteks ini pengarang menempatkan si Cepon sebagai wakil dari tokoh yang tidak berdaya menghadapi kekuasaan tokoh yang memiliki "power", yaitu Musgepuk. Si Cepon dapat dikatakan sebagai simbol dari "wong cilik" yang tidak memiliki keberdayaan dan kekuatan untuk melawan orang yang dimabuk kekuasan dan kekuatan.

Dalam cerpen ini pengarang memotret suatu kondisi sosial masyarakat kita, terutama masyarakat kecil yang selalu terpinggirkan. Melalui simbol yang diberikan Ahmad Tohari melalui cerpen "Tinggal Matanya Berkedip-kedip", ia ingin mengingatkan bahwa kekuasan dan kekuatan seorang pemimpin sebenarnya ditopang oleh kekuatan "wong cilik'. Tanpa adanya dukungan masyarakat, kekuatan seorarng pemimpin tidak ada apa-apanya. Kekuatan dan kekuasaan seorang pemimpin akan mudah runtuh saat ia tidak lagi didukung oleh masyarakatnya.

Musgepuk yang piawai dalam menjinakkan segala macam hewan ternak, tetapi memliki sifat yang sombong akhirnya kehilangan segalanya ketika si Cepon sama sekali tidak mereaksi segala perintahnya. Ia kehilangan kewibawaannya saat ia tidak dapat mengembalikan fungsi si Cepon sebagai pembajak sawah di hadapan tokoh ayah dan tokoh aku.

\section{Analisis Gramatikal dan Leksikal Penanda Kohesi Cerpen "Tinggal Matanya Berkedip-kedip"}

\section{A. Analisis Gramatikal}

Analisis aspek gramatikal dalam wacana meliputi: pengacuan, penyulihan, pelesapan, dan konjungsi. Berikut ini adalah pemaparan aspek-aspek gramatikal yang dijumpai dalam cerpen "Tinggal Matanya Berkedip-kedip".

\section{1) Pengacuan}




\section{(1) Pengacuan Persona}

Pengacuan persona yang terdapat dalam cerpen "Tinggal Matanya Berkedipkedip" meliputi pronomina persona pertama tunggal, pronomina persona pertama jamak, pronomina persona kedua tunggal, dan pronomina persona ketiga tunggal. Adapun sifat pengacuan yang ada adalah endoforis yang dapat dilihat dari data berikut:

a) 'Musgepuk bersungut-sungut. Dan uring-uringan. Semangatnya rontok. Aku, meskipun belum lama sunat, bisa mengerti perasaannya.

b) "Nah lihatlah." ujar Musgepuk sambil brdiri menghadap orangorang yang menontonnya. "Aku seorang diri telah berhasil menengkap si Cepon dan merobohkannya

c) Bertentangan dengan perasaanku, orang-orang kembali mengangguk-angguk, membuat Musgepuk makin bergairah.

d) "Yang hendak kutusukkan ini bukan apa-apa, melainkan sekadar jarum bambu"

e) "Kami tidak menyangka akhirnya si Cepon, kerbau kami, rubuh di tengah sawah yang hendak dibajak: f) "Dalam keadaan terguling di tanah, kerbau kami tidak bisa berbuat banyak"

g) "Dan kami para penonton melhat dengan jelas bahwa Musgepuk sungguh menikmati kesempatn itu"

h) 'Dasar perempuan. Apa yang membuat kau merasa ngeri?"

i) "Musgepuk kelihatan sadar betul bahwa dia berada pada saat yang tepat, yang jarang terjadi, untuk lebih menonjolkan kelebihannya.

j) "Musgepuk tertawa lebar karena merasa sayap kata-katanya sampai kepada sasaran dengan telak. Dia makin bergairah"

k) Keadaan si Cepon bertambah nista dengan darah yang terus menetes dari kedua lubang hidungnya yang dipasang kaluh; tali kekang yang menembus cingur-nya.

1) "Hayo! Hiyah! Hiyah!" teriak Musgepuk. Tangan kirinya menggoyang-goyangkan tangkai bajak. Tangan kanannya mengayunkan cambuk.

m) Masih dengan sebuah kakinya menginjak pantat si Cepon, Musgepuk mulai meraut serpih 
bambu yang sejak tadi dipegangnya.

n) "Mereka menguncupkan bahu dan menutup wajah dengan telapak tangan

Pada data a) terdapat pengacuan persona pertama tunggal bentuk bebas aku yang mengacu pada si anak pemilik kerbau yang bernama Cepon. Data b) pronomina aku mengacu pada tokoh Musgepuk Selanjutnya ku (persona pertama tunggal bentuk terikat enklitik dan proklitik) yang terdapat pada data c) mengacu pada tokoh si anak, sedangkan data d) mengacu pada tokoh Musgepuk. Persona pertama jamak terdapat pada data e), f) dan g) yakni pada kata kami. Kata kami pada data e) dan $\mathrm{f}$ mengacu pada tokoh anak dan ayahnya saja, sedangkan kata kami pada data g) tidak hanya mengacu pada tokoh anak dan ayahnya saja, tetapi juga mengacu pada para penonton.

Pengacuan persona kedua tunggal bentuk bebas kau terdapat pada data $h$ ) yang mengacu pada tokoh perempuan yang sedang menonton aksi Musgepuk saat akan menundukkan si Cepon. Bentuk ini hanya ada pada satu kalimat di atas, Adapun pengacuan persona kedua bentuk terikat tidak ditemukan pada cerpen tersebut.

Pengacuan persona ketiga tunggal bentuk bebas dia terdapat pada i) dan j) yang mengacu pada tokoh Musgepuk. Terdapat pula pengacuan persona ketiga tunggal bentuk terikat lekat kanan pada i), j) k) dan 1). Data pada i), j) dan 1) mengacu pada tokoh Musgepuk, sedangkan data k) mengacu pada tokoh si Cepon. Kata mereka pada data m) mengacu pada persona ketiga jamak, yaitu untuk menyebut orang ketiga yang lebih dari satu orang. Dalam klimat tersebut mereka untuk menunjuk para wanita yang menonton Musgepuk saat akan menjinakkan si Cepon.

Berdasarkan posisi anteseden, pada data i) dan j) terdapat anafora pada kalimat "Musgepuk kelihatan sadar betul bahwa dia berada pada saat yang tepat, yang jarang terjadi, untuk lebih menonjolkan kelebihannya dan kalimat Musgepuk tertawa lebar karena merasa sayap katakatanya sampai kepada sasaran dengan telak. Dia makin bergairah", yakni konstituen yang diacu berada di sebelah kiri konstituen pengacu, atau konstituen yang diacu disebutkan terlebih dahulu. Selanjutnya pada data $\mathrm{m}$ ) terdapat katafora, kebalikan dari anafora, konstituen yang diacu berada di sebelah kanan konstituen pengacu. Ini terdapat pada kalimat "Masih dengan sebuah kakinya menginjak pantat si Cepon, Musgepuk mulai meraut serpih bambu yang sejak tadi dipegangnya". 


\section{(2) Pengacuan Demonstratif}

Pengacuan demonstratif dapat dibedakan menjadi tiga yakni pronomina demonstratif penunjuk, pronomina demonstratif waktu (temporal), dan pronomina demonstratif tempat (lokasional). Demonstratif penunjuk misalnya, kata ini dan itu. Demonstratif waktu terdiri atas waktu sekarang, lampau, akan datang, dan waktu netral. Demonstratif tempat terdiri dari tempat dekat, agak dekat, dan jauh. Pada cerpen "Tinggal Matanya Berkedip-kedip" terdapat demonstratif waktu dan penunjuk seperti pada data berikut ini.

a) Tidak seperti pada tahun-tahun yang lalu, musim penghujan kali ini ayah dibuat pusing oleh si Cepon.

b) Ironisnya pagi ini kerbau kami rubuh secara menyedihkan di tangan pawang itu.

c) Namun kali ini pun dia siasia.Kerbau itu tetap mengonggok tanpa gerak.

Pada data a) terdapat penanda demonstratif temporal waktu lampau yaitu frase yang lalu, begitu juga pada data b) pagi ini menunjukkan waktu sekarang, sedangkan kata pawang itu sebagai demonstratif penunjuk. Selanjutnya data c) kali ini masih menunjuk pada demonstratif waktu, sedangkan kerbau itu menunjuk pada demostratif penunjuk.

\section{(3) Komparatif}

Salah satu bentuk kohesi gramatikal adalah komparatif, yaitu membandingkan dua hal atau lebih yang mempunyai kemiripan atau kesamaan dari segi bentuk/wujud, sikap, sifat, watak, perilaku, dan sebagainya. Pada cerpen "Tinggal Matanya Berkedip-kedip" terdapat komparatif sebagai berikut.

a) Kepalanya seperti terpaku mati pada leher. Seakan dia telah mendapat

pelajaran bahwa sedikit saja kepalanya bergerak berarti tali kaluh akan menggesek luka pada sekat lubang hidungnya.

b) Dia dengan ulah seperti anak kecil mendapat mainan, bersiap memasang kaluh.

c) Telinganya berputar bagai balingbaling.

d) Tak ada manusia yang merasa lebih puas daripada dia yang baru saja menerangkan arti keberadaannya.

\section{e) Dia merasa lebih perkasa daripada si Cepon.}

Pada data a) satuan lingual seperti membandingkan kepala si Cepon yang sulit untuk digerakkan karena ada tali kaluh yng menggesek pada sekat lubang 
hidung Cepon. Kata seperti diperkuat pada baris berikutnya dengan kata seakan yang menjelaskan kalimat yang sama. Adapun b) satuan lingual seperti menunjukkan perilaku Musgepuk yang sama dengan anak kecil, yaitu ketika mendapat mainan yang disukai akan senang. Data c) kata bagai menunjukkan membandingkan telinga si Cepon yang berputar-putar sama dengan baling-baling, yaitu permainan anak-anak yang terbuat dari kertas dan kalau tertiup angin akan berputar. Selanjutnya data d) dan data e) kedua-duanya menggunakan pembanding lebih......daripada $\quad$..... Pembanding tersebut menyatakan adanya kelebihan yang dimiliki seseorang daripada yang lain. Pada data d) Musgepuk sebagai seorang pawang telah menunjukkan kepuasan yang tersendiri dengan cara menerangkan eksistensinya di hadapan orang-orang yang menontonnya. Kemudian pada data e) menunjukkan kepongahan Musgepuk. Ia mengangap dirinya memliki kekuatan yang lebih dibandingkan dengan si Cepon.

\section{2) Penyulihan/Substitusi}

Penyulihan atau substitusi adalah satu jenis kohesi gramatikal yang berupa penggantian satuan lingual tertentu (yang telah disebutkan dengan satuan lingual lain dalam wacana untuk memeroleh unsur pembeda). Pada cerpen "Tinggal Matanya
Bekedip-kedip" terdapat beberapa bentuk penyulihan seperti pada data berikut ini.

\section{(1) Substitusi Nomina}

a) Kami tidak menyangka akhirnya si Cepon, kerbau kami, rubuh di tengah sawah yang hendak dibajak.

b) Musgepuk, seorang laki-laki yang kuat dan bermuka kukuh, sudah dikenal sebagai pawang bagi segala macam ternak yangdipelihara para petani.

Pada data a) satuan lingual si Cepon digantikan dengan satuan lingual kerbau kami. Kemudian pada data b) Musgepuk digantikan dengan satuan lingual seorang lak-laki yang kuat dan bermuka kukuh

\section{(2) Substitusi Kalimat}

a) "Ya, Musgepuk," kata Ayah. "Tapi tugas sampean yang sebenarnya adalah membuktikan bahwa si Cepon bisa diambil ttenaganya untuk membajak. Dan hal itu belum terlaksana.

b) Terdengar suara-suara mendesis pertanda miris. Tetapi suara itu membuat Musgepuk makin bertingkah.

Pada data a) di atas satuan lingual itu menggantikan kalimat: tugas sampean yang sebenarnya adalah membuktikan 
bahwa si Cepon bisa diambil ttenaganya untuk membajak. Begitu juga pada data b) kata itu menggantikan suara-suara mendesis pertanda miris.

\section{3) Elipsis (Pelesapan)}

Pelesapan/elipsis merupakan salah satu jenis kohesi gramatikal yang berupa penghilangan atau pelesapan satuan lingual tertentu yang telah disebutkan sebelumnya. Pelesapan dapat berbentuk kata, frasa, atau klausa. Pada cerpen "Tinggal Matanya Berkedip-kedip" umumnya pelesapan berupa kata seperti tampak pada data berikut.

a) Kami tidak nenyangka akhirnya si Cepon, kerbau kami rubuh di tengah sawah yang hendak dibajak. Ø Benarbenar rubuh tak berdaya.

b) Roman muka si Cepon, terutama matanya, bahkan ternyata $\varnothing$ bisa menunjukkan sikap pasrah total, suatu hal yang telambat diketahui oleh anak seorang petani: aku.

c) Cambuknya melecut-lecut, $\varnothing$ menambah garis-garis memar di punggung si Cepon.

d) Musgepuk bersungut-sungut. Dan $\varnothing$ uring-uringan.

e) Mereka menguncupkan bahu dan menutup wajah dengan telapak tangan. Terdengar suara-suara $\varnothing$ mendesis pertanda miris. Tetapi suara $\varnothing$ itu justru membuat Musgepuk makin bertingkah.

f) Terbukti Musgepuk bersyaraf tangguh. Tangannya terus bekerja. Tak perduli apa pun. Tidak juga $\varnothing$ air mata si Cepon yang kelihatan mengambang ketika tali ijuk yang kasar menggesek luka yang masih segar.

Pada data a) terdapat pelesapan satuan lingual berupa kata si Cepon, Kalimat itu sebelum dilesapkan berbentuk: Kami tidak menyangka akhirnya si Cepon, kerbau kami rubuh di tengah sawah yang hendak dibajak. Si Cepon benar-benar rubuh tak berdaya. Data b) terdapat pelesapan satuan lingual berupa kata matanya. Kalimat itu sebelum dilesapkan berbentuk: Roman muka si Cepon, terutama matanya, bahkan ternyata matanya bisa menunjukkan sikap pasrah total, suatu hal yang telambat diketahui oleh anak seorang petani: aku. Data c) terdapat pelesapan satuan lingual berupa kata cambuknya. Kalimat itu sebelum dilesapkan berbentuk: Cambuknya melecut-lecut, cambuknya menambah garis-garis memar di punggung si Cepon. Data d) terdapat pelesapan satuan lingual berupa kata Musgepuk. Kalimat itu sebelum dilesapkan berbentuk: Musgepuk bersungut-sungut. Dan Musgepuk uringuringan. Data e) terdapat pelesapan satuan 
lingual berupa kata mereka. Kalimat itu sebelum dilesapkan berbentuk: Mereka menguncupkan bahu dan menutup wajah dengan telapak tangan. Terdengar suarasuara mereka mendesis pertanda miris. Tetapi suara mereka itu justru membuat Musgepuk makin bertingkah.Terakhir data f) terdapat pelesapan satuan lingual berupa kata peduli. Kalimat itu sebelum dilesapkan berbentuk: Terbukti Musgepuk bersyaraf tangguh. Tangannya terus bekerja. Tak perduli apa pun. Tidak juga perduli air mata si Cepon yang kelihatan mengambang ketika tali ijuk yang kasar menggesek luka yang masih segar.

\section{4) Perangkai/Konjungsi}

Konjungsi adalah salah satu jenis kohesi gramatikal yang dilakukan dengan cara menghubungkan unsur yang satu dengan unsur yang lain dalam wacana. Dalam cerpen "Tinggal Matanya Berkedikedip" terdapat banyak konjungsi seperti pada data berikut ini.

a) Roman muka si Cepon, terutama matanya, bahkan ternyata bisa menunjukkan sikap pasrah total.

b) Kerbau kami terjerat. Dan meskipun pagar kandang berantakan, si Cepon gagal membebaskan diri. Bahkan akhirnya dia jatuh terguling ketika Musgepuk dengan jerat yang kedua, berhasil membelenggu kaki belakangnya. c) Jadi, sementara semua orang menahan rasa karena akan melihat darah mengucur dari hidung si Cepon, Musgepuk malah bermainmain, tepatnya mempermainkan perasaan orang.

d) Ayah tak berhasil mengalungkan tali lehernya apalagi memasangkan bajak. Maka ayah berbuat sesuatu yang pasti dibenarkan di kampung kami memanggil Musgepuk.(korelatif+temporal)

e) Dalam keadaan terguling di tanah, kerbau kami tidak bisa berbuat banyak. Apalagi kemudian Musgepuk juga mengikat kedua kaki depannya.(korelatif+temporal)

f) Tangan kanannya mengayunkan cambuk tetapi si Cepon tetap tak bergerak. (konjungsi koordinatif)

g) Musgepuk mencoba mengubah seruannya dengan suaranya yang lebih santun dengan harapan si Cepon akan menurut. Namun, kali ini pun dia sia-sia (adversatif)

h) Musgepuk bersungut-sungut dan uring-uringan. Aku, meskipun belum lama disunat bisa mengerti perasaannya.

(koordinatif+subordinat)

i) Boleh jadi kami terkesima karena kerbau kami yang perkasa telah terkalahkan.(K. kausal) 
j) Memang ayahku tidak suka melihat darah sehingga Ayah selalu mencar orang lain bila Emak menyuruhnya memotong ayam.

Konjungsi antarkalimat koordinatif berbentuk penegasan terdapat pada data a), b) dan c) pada kata bahkan dan malah. Pada data a) menegaskan bahwa roman muka si Cepon, terutama matanya, ternyata bisa menunjukkan sikap pasrah total. Kemudian pada data b) Selain kata bahkan yang menyatakan penegasan juga sebelum itu terdapat konjungsi koordinatif dan juga subordinatif meskipun. Konjungsi koordinatif berfungsi untuk merangkaikan kalimat pertama dan kalimat berikutnya kemudian konjungsi subordinatif meskipun untuk memperkuat kalimat berikutnya yang menegaskan bahwa pada akhirnya si Cepon jatuh terguling ketika Musgepuk dengan jerat yang kedua, berhasil membelenggu kaki belakangnya. Selanjutnya data c) diawali dengan kata penghubung antarkalimat, yaitu jadi menegaskan bahwa sementara semua orang menahan rasa karena akan melihat darah mengucur dari hidung si Cepon, justru Musgepuk mempermainkan perasaan orang.

Pada data f) terdapat konjungsi tetapi. Konjungsi ini untuk menunjukkan hubungan pertentangan antara kalimat yang pertama dan kalimat kedua. Kalimat tangan kanannya (Musgepuk) mengayunkan cambuk dipertentangkan dengan si Cepon tetap tak bergerak. Selanjutnya pada data g) terdapat konjungsi namun. Konjungsi ini menunjukkkan hubungan pertentangan antara kalimat petama dan kalimat kedua'. Kalimat Musgepuk mencoba mengubah seruannya dengan suaranya yang lebih santun dengan harapan si Cepon akan menurut dipertentangkan dengan kalimat kali ini pun dia sia-sia Pada data i) terdapat konjungsi karena yang menyatakan kalimat pertama sebagai akibat dari kalimat kedua

\section{B. Analisis Leksikal}

Kepaduan wacana selain didukung oleh aspek gramatikal atau kohesi gramatikal juga didukung oleh kohesi leksikal. Aspek leksikal adalah hubungan antarunsur dalam wacana secara semantis. Analisis aspek leksikal dalam wacana meliputi: reiterasi dan kolokasi. Reiterasi menurut Zaimar dan Ayu Basoeki Harahap (2009:140) adalah pengulangan makna, baik seluruhnya maupun sebagian. Ada bermacam-macam reiterasi, yaitu repetisi, sinonim, hiponim, dan kata generik. Dalam tulisan ini hanya dibahas repetisi dan sinonim.

Berikut ini adalah pemaparan aspek-aspek leksikal yang dijumpai dalam 
cerpen "Tinggal Matanya Berkedipkedip".

\section{Repetisi}

a) Aku seorang diri telah berhasil telah menankap si Cepon dan merebahkannya. Seorang diri.

b) "Yang hendak kutusukkan ini bukan apa-apa, melainan sekadar jarum bambu. Yang hendak kutusuk juga bukan apa-apa melainkan sekadar cingur kerbau dungu.

c) Oh, itu gampang. Gampang! Sampean akan melihat nanti si Cepon yang baru kujinakkan ini akan menggarap sawah sampean dengan gampang.

d) Tetes darah makin serng eluncur dn hidung kerbau kami membuat rona merah di atas lumpur melebar dan melebar.

e) Kami tidak menyangka akhirnya si Cepon, kerbau kami, rubuh di tengah sawah yang hendak dibajak. Benarbenar rubuh.
Contoh
a) dan
b) merupakan repetisi anafora karena berupa perulangan satuan lingual kata atau frasa pertama pada tiap baris atau kalimat berikutnya.
Contoh
c) dan
d) merupakan

repetisi epizeukis karena berupa perulangan satuan lingual (kata) yang dipentingkan beberapa kali secara berturut-turut. Contoh e) merupakan repetisi mesodiplosis karena merupakan perulangan satuan lingual di tengah-tengah baris atau kalimat secara berturut-turut.

\section{Sinonimi}

Sinonimi merupakan aspek leksikal guna mendukung kepaduan wacana. Sinonim dipakai untuk menjalin hubungan makna yang sepadan antara satuan lingual lain dalam wacana.

a) Barangkali sisa tenaganya habis buat meronta, memberontak dari cengkeraman bajak yang membelenggu lehernya.

b) Musgepuk, seorang laki-laki yang kuat dan bermuka kukuh sudah dikenal sebagai pawang bagi segala macam ternak yang dipelihara para petani.

c) Benar-benar rubuh, tak berdaya.

Pada contoh a) kata meronta bersinonim dengan kata memberontak. Kemudian pada contoh b) kata kuat disinonimkan dengan kata kukuh. Terakihr pada contoh c) kata rubuh disinonimkamkan dengan kata tak berdaya.

\section{Simpulan}

Dari uraian di atas dapat disimpulkan bahwa cerpen "Tinggal 
Matanya Berkedip-kedip" karya Ahmad

Tohari ditinjau dari aspek situasional yang tergambar melalui cerpen tersebut bahwa tokoh utama, yaitu si Cepon (seekor kerbau) akhirnya roboh. Robohnya si Cepon justru menyebabkan hancurnya kewibawaan Musgepuk sebagai pawang binatang piaraan. Dia yang selalu membanggakan kepiawaiannya menjinakkan bintang piaraan menjadi tidak berdaya di hadapan si Cepon yang justru tidak melakukan perlawanan apa pun. Musgepuk merupakan simbol dari seseorang yang memiliki kekuasaan. Dengan kekuasaannya dia berlaku sombong. Dengan kesombongannya itu akhirnya dia jatuh.

Dalam cerpen ini pengarang memotret suatu kondisi sosial masyarakat kita,terutama masyarakat kecil yang selalu terpinggirkan. Melalui simbol yang diberikan Ahmad Tohari melalui cerpen "Tinggal Matanya Berkedip-kedip", ia ingin mengingatkan bahwa kekuasan dan kekuatan seorang pemimpin sebenarnya ditopang oleh kekuatan "wong cilik'. Tanpa adanya dukungan masyarakat, kekuatan seorarng pemimpin tidak ada apa-apanya. Kekuatan dan kekuasaan seorang pemimpin akan mudah runtuh saat ia tidak lagi didukung oleh masyarakatnya.

Aspek gramatikal yang meliputi: pengacuan, penyulihan, pelesapan, dan konjungsi juga tampak dalam cerpen
"Tinggal Matanya Berkedip-kedip". Pengacuan yang digunakan di dalam cerpen "Tinggal Matanya Berkedip-kedip" yaitu persona pertama tunggal bentuk bebas aku/ku. Persona tersebut mengacu pada tokoh si anak pemilik kerbau dan tokoh Musgepuk. Persona pertama jamak yaitu kami digunakan juga. Persona tersebut mengacu pada tokoh anak, ayah, dan para penonton.Persona ketiga yaitu "di" dan "mereka". Pengacuan lain yang tampak adalah demontratif dengan penggunan kata "ini"," itu"

Aspek leksikal yang berupa repetisi dan sinonim yang digunakan pengarang berfungsi mempertegas serta menguatkan pernyataan yang ingin disampaikan. Pengulangan kata gampang, misalnya, untuk menguatkan bahwa si tokoh mampu melaksanakan tugas yang diberikan kepadanya. Kemudian penggunaan sinonim untuk mempertegas serta menguatkan sesuatu yang ingin disampaikan pengarang. Penggunaan repetisi dan sinonim telah membuat cerpen "Tinggal Matanya Berkedip-kedip menjadi lebih menarik.

\section{Daftar Rujukan}

Djojosuroto, Kinayati dan Noldy Pelenkahu. 2009. Teori Apresiasi dan Pembelajaran Prosa. Yogyakarta: Pusaka Book Publisher. 
Junaiyah H.M. dan E. Zaenal Arifin. 2010. Keutuhan Wacana. Jakarta: PT Grammedia Widiasarna Indonesia.

Nurgiyantoro, Burhan. 2010. Teori Pengkajian Fiksi. Yogyakarta: Gadjah Mada University Press.

Siswanto, Wahyudi. 2008. Pengantar Teori Sastra. Jakarta: PT Grasindo.

Tohari, Ahmad. 1989. Kumpulan Cerpen Senyum Karyamin. Jakarta: PT Gramedia.

Zaimar. Okke Kusuma Sumantri dan Ayu Basuki Harahap. 2009. Telaah Wacana.Jakarta: The Intercultural Institute 